\title{
Próba uchwycenia charakteru prawnego instytucji zaręczyn oraz skutki związane $z$ ich odwolaniem w świetle prawa polskiego ze wskazaniem regulacji w prawie niemieckim i włoskim
}

\begin{abstract}
Gdy z ustawodawstwa polskiego likwidowano regulację prawną zaręczyn, w środowisku prawniczym panowało powszechne przekonanie o braku potrzeby istnienia takiej kodyfikacji prawnej. Znaczenie obietnicy małżeństwa umniejszono raczej do rangi zakorzenionego w historii obyczaju, odmawiając jej doniosłości prawnej. Obecnie doktryna przyjmuje różne koncepcje, które mogłyby określić charakter prawny zaręczyn. Oprócz wskazania rysu historycznego instytucji zaręczyn, w niniejszym artykule znalazły się teoretyczne rozważania na temat charakteru prawnego przyrzeczenia małżeństwa. Z praktycznego punktu widzenia tego zwyczaju niezwykle istotne zdało się także wskazanie rozwiązań prawnych, jakie mogą mieć zastosowanie w przypadku ewentualnej odpowiedzialności odszkodowawczej nupturienta zrywającego przyrzeczenie $\mathrm{W}$ związku $\mathrm{z}$ wydatkami poczynionymi na organizację zaślubin i przyjęcia weselnego. Całość dopełnia odniesienie do jurydycznych uregulowań zaręczyn w prawie niemieckim oraz włoskim.
\end{abstract}

\section{Sponsalia sunt mentio et repromissio nuptiarum futurarum}

Instytucja zaręczyn znana była już w dziejach Starego Testamentu, ale jej prawdziwy rozkwit jurydyczny nastąpił w prawie rzymskim ${ }^{1}$. Opisując to pojęcie należy przede wszystkim sięgnąć do definicji zaręczyn, jaką sformułował Florentinus: „Sponsalia sunt mentio et repromissio nuptiarum futurarum”, co tłumaczy się jako „,zapowiedź i wzajemne przyrzeczenie zawarcia małżeństwa w przyszłości”" Termin ten pochodzi od słowa sponsio, czyli uroczystego kontraktu słownego, jaki zawierany był w czasach najodleglejszych. Dokonać tego mogli ojcowie zaręczających się albo też sami oblubieńcy, pod warunkiem,

\footnotetext{
${ }^{1}$ W. Góralski, Zaręczyny [w:] Encyklopedia katolicka, t. 20, Lublin 2014, s. 1255.

${ }^{2}$ W. Włodkiewicz, M. Zabłocka, Prawo rzymskie. Instytucje, wyd. 5, Warszawa 2009, s. 92.
} 
że byli osobami sui iuris $^{3}$. Wówczas za niedotrzymanie umowy, na mocy której kobieta oddawana była pod władzę przyszłego męża, groziła zapłata kary pieniężnej. W dalszych okresach zaręczyny straciły nieco na znaczeniu i były zawierane w drodze tzw. nudus consensus, czyli nieformalnego już tylko porozumienia, którego zerwanie nie rodziło żadnych konsekwencji ${ }^{4}$. Dopiero $\mathrm{w}$ dominacie zaręczyny zaczęły wywoływać poważniejsze skutki prawne, o czym stanowiło na przykład uwzględnienie narzeczonych przy przestępstwie zwanym parricidium ${ }^{5}$. Stosunek jaki łączył nupturientów nazywany był quasiadfinitas i oznaczał prawie tyle co powinowactwo ${ }^{6}$. Parricidium zaś był czynem zabronionym, polegającym na zabiciu, pierwotnie tylko rodzicieli, później też innych bliskich osób, w tym właśnie narzeczonych, zagrożonym tzw. poena cullei. Była to niezwykle okrutna kara tzw. skórzanego worka, w którym umieszczano skazanego wraz ze zwierzętami, a następnie wrzucano go do morza ${ }^{7}$. W okresie prawa poklasycznego, na mocy rozporządzeń cesarskich z IV w. n.e. wprowadzono tzw. arra sponsalicia, czyli zadatek zaręczynowy. W razie zerwania zaręczyn przez mężczyznę tracił on dany zadatek, jeśli zaś dokonała tego kobieta, zobowiązana była zwrócić go, z reguły, w podwójnej wysokości. Czas trwania zaręczyn musiał wynosić wówczas minimum dwa lata ${ }^{8}$ W czasach ustawodawstwa Konstantyna Wielkiego nawet pocałunkowi zaręczynowemu nadano pewne znaczenie prawne. Zwyczajem było też dokonywanie darowizn na rzecz przyszłych małżonków. Konstantyn uważał jednak, iż powinny być one dokonywane pod warunkiem zawarcia małżeństwa w przyszłości. W razie rozwiązania zaręczyn, narzeczeni zwracali sobie podarunki, chyba że któreś z nich ponosiło ewidentną winę za niedojście do skutku małżeństwa9

Wczesne średniowiecze nadawało małżeństwu świecki charakter. Akt ten podzielony był wówczas na dwa etapy. Pierwszy z nich - zmówiny, stanowiły swego rodzaju odzwierciedlenie dzisiejszych zaręczyn. Narzeczony zawierał z opiekunem przyszłej żony umowę, która ściśle określała zasady oraz termin zawarcia związku małżeńskiego. Towarzyszyło temu uiszczenie ceny kupna lub zadatku, a często także przedmioty symbolizujące dokonanie zobowiązania. Czasami też mówi się o osobie, która pośredniczyła

\footnotetext{
${ }^{3} \mathrm{~W}$ odróżnieniu od osób alieni iuris, były to osoby, które nie podlegały niczyjej władzy w rodzinie, zwłaszcza niezwykle rozległej władzy naczelnika rodziny - pater familias. Zob. W. Włodkiewicz, M. Zabłocka, op.cit., s. 81-83.

${ }^{4}$ W. Włodkiewicz, M. Zabłocka, op.cit., s.92.

${ }^{5}$ W. Litewski, Rzymskie prawo prywatne, wyd. 2, Warszawa 1995, s. 162.

${ }^{6}$ W. Włodkiewicz, M. Zabłocka, op.cit., s.92.

${ }^{7}$ A. Dębiński, Poena cullei w rzymskim prawie karnym, „Prawo Kanoniczne: kwartalnik prawno-historyczny” 1994, nr 37, s. 133.

${ }^{8}$ W. Litewski, op.cit., s. 162.

${ }^{9}$ H. Insadowski, Rzymskie prawo matżeńskie a chrześcijaństwo, Lublin 1935, s. 38-48.
} 
między nimi, tzw. dziewosłębie. Na mocy tej umowy mężczyzna otrzymywał przyrzeczenie dokonania drugiego etapu, jakim była uroczystość zdawin, podczas której kobieta oddawana była w ręce pana młodego ${ }^{10}$.

Jeśli chodzi o prawo kościelne, początkowo przejęto zasady, jakie panowały w prawie rzymskim. $Z$ czasem pojawiały się coraz to nowsze regulacje prawne, a co za tym idzie, sprzeczności i problemy. Jedną z nich był wymóg zawierania zaręczyn z błogosławieństwem duchownego, inną - surowszą - nakaz składania obietnicy małżeństwa na piśmie, w niektórych przypadkach nawet pod rygorem nieważności ${ }^{11}$. Proboszczom nakazano obowiązkowe prowadzenie ksiąg zaręczonych. W 1573 r. Sobór Trydencki próbował nawet ustalić jedną wiążącą formę zawarcia zaręczyn, jednak bezskutecznie. Dopiero w 1907 r. wydany przez papieża Piusa X dekret „Ne temere” przekształcił nieformalny dotąd fakt zaręczyn w uroczysty akt prawny, przypisując mu stałą formę pisemną, dokonywaną w obecności i z udziałem proboszcza lub przynajmniej dwóch świadków, pod rygorem nieważności. Mimo wszystko procedura ta nie zobowiązywała ostatecznie nupturientów do zawarcia związku małżeńskiego ${ }^{12}$. Profesor Władysław Abraham uważa, że już w tamtym czasie niedopuszczalne było uwzględnianie kary umownej w piśmie dotyczącym aktu zaręczyn, natomiast umowa o wynagrodzenie wyrządzonej szkody w razie bezprawnego ich zerwania była jak najbardziej dopuszczalna. Ponadto, wszelkie umowy czy klauzule modyfikujące, które wiążą się z zawarciem zaręczyn, a nawet umówienie zadatku były skuteczne tylko, jeśli zostały spisane i objęte umową zaręczyn. Pismo to musiało być także własnoręcznie podpisane przez nupturientów, świadków i plebana ${ }^{13}$.

Kodeks Prawa Kanonicznego z 1917 r. nadal afirmował formę pisemną zaręczyn i uznawał je za uroczyste przyrzeczenie zawarcia małżeństwa w przyszłości, jednak nie wywodził z niego roszczenia, którego można by było dochodzić na drodze sądowej. Mimo tego wskazywał na możliwość domagania się strat, jakie strona poniosła wskutek ich zerwania ${ }^{14}$. Przyrzeczenie zaręczyn było fakultatywne, aczkolwiek zalecano je jako pewnego rodzaju przestrzeń na oswojenie się z podjętą decyzją i przygotowanie do zaślubin.

\footnotetext{
${ }^{10}$ Katarzyna Sójka-Zielińska, Historia prawa, wyd. 15, Warszawa 2015, s. 89.

${ }^{11} \mathrm{~Np}$. ustawa króla Karola IV z 24.8.1804 r., według której, aby zaręczyny mogły być uznane za ważne, musiały zostać zawarte w formie aktu notarialnego.

${ }^{12}$ W. Orawiecki, Zaręczyny $w$ tradycji Kościoła Powszechnego i współczesnym prawie kanonicznym, Wrocław 2008, s. 53-80.

${ }^{13}$ W. Abraham, Forma zawarcia zaręczyn i matżeństwa $w$ najnowszem ustawodawstwie kościelnym, wyd. 2 , Lwów 1913, s. 63-74.

${ }^{14}$ W. Góralski, op.cit., s. 1256.
} 
Przesłankami ważności były m.in. zdolność do podejmowania czynności prawnych, świadomość i dobrowolność, a także prawdziwość złożonego przyrzeczenia ${ }^{15}$.

Wreszcie obowiązujący Kodeks Prawa Kanonicznego promulgowany przez papieża Jana Pawła II 25.1.1983 r. uregulował instytucję zaręczyn w kanonie 1062 stanowiąc, że przyrzeczenie małżeństwa od tej pory ,regulowane jest prawem partykularnym, ustanowionym przez Konferencję Episkopatu $z$ uwzględnieniem zwyczajów oraz prawa świeckiego, gdy takie zostało wydane”. Rozwiązanie to wydaje się najbardziej adekwatne do obecnych czasów. Regulacja prawna zaręczyn została słusznie scedowana na instytucje będące najbliżej ludzi, które znają lokalne obyczaje i normy prawa państwowego. Głównym założeniem jest obecnie szerzenie świadomości znaczenia instytucji zaręczyn i ochrona przed jej upadkiem. Jak w prawie rzymskim, jest to uroczyste przyrzeczenie i jak w późniejszym ustawodawstwie, nie można wywodzić z niego roszczenia o zawarcie małżeństwa. „Przystuguje jednak skarga o wynagrodzenie szkód, jeśli takie powstaty” ${ }^{16}$.

\section{Próba ustalenia charakteru prawnego zaręczyn}

\subsection{Regulacje prawne zaręczyn}

Polski ustawodawca nie zdecydował się obecnie na normatywne uregulowanie zaręczyn. Prawna regulacja niegdyś jednak istniała. Ostatnim aktem prawnym w dziejach ustawodawstwa polskiego traktującym o instytucji zaręczyn wprost był Dekret z 25.9.1945 r. Prawo małżeńskie ${ }^{17}$. Wyrażona $\mathrm{w}$ nim ogólna reguła, że nie istnieje prawna możliwość wniesienia powództwa o zawarcie małżeństwa $\mathrm{z}$ tytułu zaręczyn obowiązuje do dziś. Jednocześnie jasno określono konsekwencje prawne bezpodstawnego zerwania przyrzeczenia. Wraz z uchwaleniem Kodeksu rodzinnego w 1950 r. ${ }^{18}$ dekret ten został uchylony. Od tamtej pory środowisko prawnicze zmaga się z określeniem charakteru prawnego zaręczyn, a przede wszystkim z kwestią odpowiedzialności odszkodowawczej za wydatki poczynione w związku $\mathrm{z}$ organizacją zaślubin.

Zważając na to, że wszelka definicja w prawie cywilnym jest niebezpieczna, a jednocześnie chcąc nieco przybliżyć się do ustalenia charakteru prawnego instytucji zaręczyn, warto odnieść się do kilku aspektów. Zacząć należy od ustalenia kategorii, w których mieszczą

\footnotetext{
${ }^{15}$ W. Orawiecki, op.cit., s. 119-126

${ }^{16}$ Ibidem, s. 156-158.

${ }^{17}$ Dz.U. Nr 48, poz. 270.

${ }^{18}$ Ustawa z 27.6.1950 r. - Kodeks rodzinny, Dz.U. Nr 34, poz. 308.
} 
się zaręczyny. Należy rozważyć, czy można uznać je za zdarzenie prawne, swego rodzaju zobowiązanie naturalne, a może pewien typ czynności prawnej. Jest to niezwykle istotne, zwłaszcza w zakresie rozstrzygania o ewentualnych roszczeniach prawnych, które niewątpliwie pojawiają się w tego typu stosunkach osobistych.

\subsection{Zaręczyny jako czynność podobna do czynności prawnej}

Odpowiedź na powyższe pytania wypadałoby rozpocząć od przytoczenia definicji podstawowego pojęcia nauki prawoznawstwa, jakim jest wspomniane już zdarzenie prawne. Istotą zdarzenia cywilnoprawnego jest powstanie, zmiana lub ustanie stosunku prawnego, którego koniecznymi elementami są $\mathrm{z}$ jednej strony prawo podmiotowe, $\mathrm{z}$ drugiej zaś odpowiadający temu prawu obowiązek ${ }^{19}$. W myśl ustawodawstw wielu krajów, które zdecydowały się na regulację prawną zaręczyn, a także przeważającego poglądu, że z tytułu ich zawarcia nie można wywodzić roszczenia o zawarcie małżeństwa, należałoby przyjąć, że żadnej ze stron nie przysługuje ani uprawnienie, ani obowiązek.

Czy w tym świetle możliwe jest uznanie zaręczyn za zdarzenie prawne? Teoretycznie jest to niemożliwe. Jednakowoż prof. Zbigniew Radwański sformułował typologię zdarzeń prawnych, w której obok czynności prawnych sensu stricto wyróżnił też ,,działania prawne zbliżone do czynności prawnych i dlatego wymagajace łacznego rozważenia z czynnościami prawnymi”, zaliczając do tej kategorii przejawy uczuć20. Czym innym są zaręczyny, jeśli nie przejawem uczuć? Określenie zaręczyn jako zdarzeń zbliżonych do czynności prawnych wynika z faktu, że jak te ostatnie, zawierają one swego rodzaju wypowiedzi, które nie posiadają charakteru oświadczeń woli sensu stricto, ale wyrażają pewien sens i przeznaczone są do obwieszczania innym ludziom, przez co zyskują cechę doniosłości społecznej. W związku z tym dopuszczalne jest stosowanie do nich w drodze analogii instytucji, które bezpośrednio odnoszą się do czynności prawnych w ścisłym znaczeniu ${ }^{21}$. Pogłębiając tę analizę K. Mularski zaliczył instytucję zaręczyn do ,ewidentnie znakowych (konwencjonalnych) zachowañ”, które mieszczą się w kategorii czynności podobnych do czynności prawnych i nietrafnie często uznawane są jedynie za czynność faktycznąa22.

\footnotetext{
${ }^{19}$ Z. Radwański, A. Olejniczak, Prawo cywilne - część ogólna, wyd. 12, Warszawa 2013, s. 83-90, $214-215$.

${ }^{20}$ Ibidem, s. 215-217.

${ }^{21}$ Ibidem, s. 219-220.

${ }^{22}$ K. Mularski, Czynności podobne do czynności prawnych, Warszawa 2011, s. 97-100.
} 
Ściśle trzymając się przedstawionej koncepcji, instytucja zaręczyn nie powinna być zaliczana do kategorii czynności prawnych sensu stricto, a jedynie można ją traktować jako swego rodzaju czynność podobną do czynności prawnych.

Zaręczyny nie są uznawane za jednostronną czynność prawną, o ile w ogóle do czynności prawnych mogą być zakwalifikowane. Doktryna wyraźnie bowiem przyjmuje pogląd o normatywnym zamkniętym katalogu jednostronnych czynności prawych ${ }^{23}$. Kreują go instytucje uregulowane przede wszystkim w Kodeksie cywilnym, a także licznych ustawach szczegółowych. Niemożliwe jest tworzenie zobowiązań, czyli stanowienia źródła roszczeń poprzez czynności jednostronne, które nie mieszczą się $\mathrm{w}$ tym katalogu ${ }^{24}$. Ze względu na brak normatywnej regulacji zaręczyny nie mogą być zakwalifikowane do jednostronnych czynności prawnych.

\subsection{Zaręczyny jako umowa sui generis}

Ze względów praktycznych, a także z uwagi na zaszłości uregulowań prawnych tej instytucji w latach wcześniejszych, w doktrynie przyjęło się uznawać zaręczyny za swoistego rodzaju umowę ${ }^{25}$. By zrozumieć tę koncepcję, należy odnieść się do swobód zagwarantowanych jednostkom w różnych aktach prawnych. W pierwszej kolejności niezbędne jest wskazanie na unormowania Konstytucji ${ }^{26}$, następnie zaś na regulacje prawa cywilnego i aktów prawa międzynarodowego, które pozwalają odnaleźć pewien kontekst i na jego tle formułować wnioski.

Artykuł 47 Konstytucji wyraża zasadę swobody kształtowania życia osobistego i kreuje prawo do ochrony życia prywatnego, rodzinnego i podejmowania decyzji o życiu osobistym. Zaręczyny wpisują się w obszar życia osobistego i rodzinnego, które Konstytucja chroni w sposób szczególny. Dalekim odniesieniem będzie tu art. 18 Ustawy Zasadniczej i zapewniona w nim ochrona związku małżeńskiego kobiety i mężczyzny, do czego wstępem są właśnie zaręczyny. Swobodę zawarcia związku małżeńskiego zapewnia prawo

\footnotetext{
${ }^{23}$ Z. Radwański, A. Olejniczak, Zobowiązania - część ogólna, wyd. 11, Warszawa 2014, s. 25-26.

${ }^{24}$ Wyrok Sądu Najwyższego z 17.7.2009 r., sygn. akt: I PK 26/2009, Lex nr 523544.

${ }^{25}$ Zob. J. Gajda [w:] T. Smyczyński (red.), System prawa prywatnego. Prawo rodzinne i opiekuńcze. Tom 11, Warszawa 2009, s. 73-75.

${ }^{26}$ Konstytucja Rzeczypospolitej Polskiej z 2.4.1997 r., Dz.U. Nr 78, poz. 483.
} 
międzynarodowe, między innymi w Karcie Praw Podstawowych ${ }^{27}$ i Konwencji o ochronie praw człowieka i podstawowych wolności ${ }^{28}$.

Zaręczyny pozostają prawnie niezdefiniowanym, jednak jednocześnie powszechnie obowiązującym zwyczajem. Wynikają z nich pewne skutki cywilnoprawne, a to za sprawą obowiązującej w prawie polskim zasady swobody kształtowania treści stosunków zobowiązaniowych za pomocą umów. Wyrażona w art. $353^{1}$ Kodeksu cywilnego $^{29}$ zasada swobody zawierania umów jest często definiowana jako kompetencja stron umowy do kształtowania wiążących je stosunków prawnych, za pomocą składanych wzajemnie oświadczeń woli ${ }^{30}$. Jest to zatem swego rodzaju uprawnienie do formułowania stosunku zobowiązaniowego, innego niż te wyznaczone przepisami prawa ${ }^{31}$. Niektórzy przedstawiciele doktryny uważają jednak, że bezpieczniejsze jest definiowanie zasady swobody umów tylko przez określenie jej granic ${ }^{32}$. Artykuł $353^{1}$ k.c. wyraźnie bowiem wskazuje, że strony mogą dowolnie określić treść stosunku prawnego, ale też zdecydować o tym, czy w ogóle chcą go ze sobą zawrzeć, byleby tylko treść oraz cel tegoż stosunku nie były sprzeczne z jego właściwością (naturą), ustawą ani zasadami współżycia społecznego (powszechnie akceptowanym $\mathrm{w}$ społeczeństwie normom moralnym) ${ }^{33}$. Zastosowanie ma tu powszechne sformułowanie, że ,wszystko, co nie jest zabronione (wyjątek), jest stronom dozwolone (reguła) "34. Określenie granic swobody umów zaczyna się tam, „gdzie kończy się wolność stron w kształtowaniu stosunku prawnego"35. Przekroczenie tychże granic sankcjonowane jest jego nieważnością lub też inną dotkliwością przewidzianą przepisami prawa ${ }^{36}$.

Chociaż uważa się, że zasada swobody umów nie ma odniesienia do stosunków rodzinnych, to jednocześnie zgodnie z przeważającym poglądem doktryny uznaje się instytucję zaręczyn za swoistego rodzaju umowę, której zawarcie ,jest dozwolone na zasadach

\footnotetext{
${ }^{27}$ Artykuł 9. Karty Praw Podstawowych Unii Europejskiej, Dz.Urz.UE 2012 Nr C 326/02.

${ }^{28}$ Artykuł 12. Konwencji o Ochronie Praw Człowieka i Podstawowych Wolności z 4.11.1950 r., Dz.U. z 1993 r., Nr 61, poz. 284.

${ }^{29}$ Ustawa z 23.4.1964 r. - Kodeks cywilny, tekst jedn. Dz.U. z 2017 r. poz. 459 ze zm.

${ }^{30}$ Z. Radwański, A. Olejniczak, Zobowiązania ..., s. 130-132.

31 W głównej mierze chodzi o katalog umów nazwanych, ale należy także wziąć pod uwagę szereg umów nienazwanych, określanych jako empiryczne, których ramy prawne kształtowane, a następnie ujednolicane przez lata praktyki, drogą zwyczajów oraz wielu analiz powodują, iż zaczynają być traktowane w doktrynie i orzecznictwie jako odrębnego typu umowy nazwane. Zob. W. Katner [w:] W. Katner (red.), System prawa prywatnego. Prawo zobowiąań - umowy nienazwane. Tom 9, wyd. 2, Warszawa 2015, s. 12-14.

${ }_{32}$ W. Katner [w:] W. Katner (red.), System prawa prywatnego. Prawo zobowiązań - umowy nienazwane. Tom 9, wyd. 2, Warszawa 2015, s. 3-6.

${ }^{33}$ Z. Radwański, A. Olejniczak, Zobowiązania..., s. 131-137

${ }^{34}$ W. Czachórski, A. Brzozowski, M. Safjan, E. Skowrońska-Bocian, op.cit., s. 146.

${ }^{35}$ W. Katner, op.cit., s. 5.

${ }^{36}$ Z. Radwański, A. Olejniczak, Zobowiązania..., s. 137.
} 
ogólnych"37. Kobieta i mężczyzna (strony) wspólnie oświadczają, że w przyszłości pragną zawrzeć związek małżeński (przedmiot), dlatego będą lojalnie wobec siebie dążyć do spełnienia obietnicy (dorozumiane prawa i obowiązki stron). Wydaje się, że przytoczona sytuacja spełnia wymogi istnienia umowy. Co więcej, możliwe zdaje się wpisanie jej w konwencję umowy nienazwanej. Instytucja zaręczyn nie została nigdzie skodyfikowana, nie istnieje zatem katalog elementów przedmiotowo dla niej istotnych, ani też nie można utożsamić jej z jakąkolwiek umową nazwaną. Treść i cel zaręczyn pozostaje zgodny z prawem i zasadami współżycia społecznego. Wątpliwa jest jedynie kwestia nazewnictwa ${ }^{38}$.

\subsection{Zaręczyny jako umowa przedwstępna}

Czy w związku z uznaniem zaręczyn za pewnego rodzaju umowę, a także wobec tego, że stanowią one przyrzeczenie zawarcia w przyszłości związku małżeńskiego, można uznać je za umowę przedwstępną? Prima facie taka kwalifikacja zdawałaby się prawidłowa. Dokonawszy nieco głębszej analizy konstrukcji pactum de contrahendo, przyporządkowanie doń instytucji zaręczyn jest jednak wykluczone. Przede wszystkim wynika to z okoliczności, że o uznaniu umowy za umowę przedwstępną świadczy zobowiązanie się chociażby jednej ze stron do wykonania umowy stanowczej39. Oświadczyny jednego z zakochanych ${ }^{40}$ nie wystarczą, skoro o zawarciu zaręczyn świadczy ,wzajemne przyrzeczenie sobie mał̇eństwa" ${ }^{41}$, wskazujące na działanie dwóch stron. Drugim argumentem przemawiającym przeciwko temu stanowisku jest konieczność określenia essentialia negotii umowy przyrzeczonej i innych postanowień, bez których jej zawarcie byłoby niemożliwe ${ }^{42}$. Trudno jest określić owe elementy w wypadku zaręczyn. Dodatkowo niezbędnym jest wskazanie terminu zawarcia umowy stanowczej i ewentualne wyznaczanie go przez drugą stronę w późniejszym czasie, abstrakcyjne w analizowanym przypadku. Kolejną wątpliwość niesie ustalenie formy umowy przedwstępnej. Najbardziej doniosłe konsekwencje prawne rodzi zawarcie jej z zachowaniem wymaganej dla umowy definitywnej formy szczególnej, zastrzeżonej pod rygorem nieważności ${ }^{43}$. Można wówczas wystąpić do sądu o wydanie orzeczenia,

\footnotetext{
${ }^{37}$ J. Ignatowicz, M. Nazar, Prawo rodzinne, wyd. 4, Warszawa 2012, s. 112-113.

${ }^{38}$ Zob. W. Katner, op.cit., s. 11-23.

${ }^{39}$ M. Krajewski, Umowa przedwstepna, wyd. 2, Warszawa 2002, s. 103.

${ }^{40}$ Zob. Oświadczyny, [w:] Stownik wspótczesnego języka polskiego, red. B. Dunaj, Warszawa 1996, s. 703.

${ }^{41}$ Zaręczyny, [w:] Stownik współczesnego języka polskiego, red. B. Dunaj, Warszawa 1996, s. 1333.

42 A. Kondracka, Pojęcie i charakter prawny umowy przedwstępnej, „Monitor Prawniczy” 1999, nr 3, www.czasopisma.beck.pl [dostęp: 7.7.2017].

${ }^{43} \mathrm{~Np}$. w formie aktu notarialnego, gdy umowa przedwstępna dotyczy umowy sprzedaży nieruchomości.
} 
które po uprawomocnieniu się, zastępuje oświadczenie woli jednej ze stron umowy ${ }^{44}$. W przypadku zaręczyn takie rozwiązanie wydaje się godzić w swobody zagwarantowane obywatelom. Tym bardziej niedorzeczne byłoby zastrzeżenie zadatku czy kary umownej. Za niezasadnością tej koncepcji najbardziej przemawia przede wszystkim inny cel umowy przedwstępnej, zawieranej jako czynność kauzalna, która wywołuje skutki prawne o charakterze rozporządzającym i zobowiązującym, co tym bardziej podkreśla jej użyteczność w sferze stosunków materialnych, a nie osobistych ${ }^{45}$.

\subsection{Zaręczyny jako obligatio naturalis}

W związku z tym, że niedopuszczalne jest dochodzenie zawarcia związku małżeńskiego na podstawie zaręczyn, co oznacza zakaz przymusowego dochodzenia roszczenia przez wierzyciela, ostatnią kwestią, jaką wypada poruszyć przy okazji określania charakteru prawnego zaręczyn, jest dylemat związany z traktowaniem ich jako obligatio naturalis. Podstawową cechą zobowiązania naturalnego jest jego niezaskarżalność. Oznacza, że dłużnik nie ponosi odpowiedzialności za swój dług, wierzyciel zaś nie ma prawa wystąpić z roszczeniem o wydanie orzeczenia czy też przeprowadzenie przymusowej egzekucji ${ }^{46}$.

Przywołując koncepcję o uznaniu zaręczyn za czynność pobodną do czynności prawnej sensu stricto oraz określenie ich jako swego rodzaju umowę, pojawia się problem związany z tym, czy można traktować je jak zobowiązanie. Czy można w ich kontekście mówić o długu? Wydaje się to wykluczone. Już same określenia godzą w swobody prawnie zagwarantowane obywatelom. Chociaż przyjmuje się, że każdy przypadek takiego zobowiązania niezupełnego powinien zostać potraktowany indywidualnie, doktryna spójnie wyróżnia tylko dwie kategorie zobowiązań niezupełnych: związane $\mathrm{z}$ przedawnieniem roszczenia oraz zobowiązania wynikające $z$ gier i zakładów ${ }^{47}$.

\section{Dochodzenie roszczeń związanych z niespełnieniem przyrzeczenia małżeństwa}

Choć jako niemoralne można traktować wstąpienie w związek małżeński osoby, która uprzednio zawarła zaręczyny z kimś innym, zaś roszczenia o zawarcie związku

\footnotetext{
${ }^{44}$ Z. Radwański, A. Olejniczak, Zobowiązania..., s. 148.

${ }^{45}$ A. Kondracka, op.cit., [dostęp: 7.7.2017].

${ }^{46}$ Z. Radwański, A. Olejniczak, Zobowiązania ..., s. 22.

${ }^{47}$ Ibidem, s. 22-23.
} 
małżeńskiego rzekomo wynikającego z zaręczyn naruszają porządek prawny, nierozstrzygnięta pozostaje kwestia wzajemnych, majątkowych roszczeń niedoszłych małżonków. Brak regulacji prawnej zaręczyn staje się nader kłopotliwy, w szczególności ze względu na olbrzymie sumy, jakie wydaje $\mathrm{w}$ związku $\mathrm{z}$ organizacją ślubu i przyjęcia weselnego. Powszechnie dostępne statystyki pokazują, że choć z roku na rok liczba nowych małżeństw jest coraz mniejsza, wydatki na organizację imprez weselnych rosną. Corocznie Polacy są w stanie wydać nawet 10-12 miliardów złotych na przygotowanie uroczystości weselnej ${ }^{48}$.

W opisanej sytuacji zastosowanie znajdzie art. 415 k.c., który stanowi o ogólnej zasadzie odpowiedzialności za własne czyny, bowiem kto z winy swojej wyrządził szkodę drugiej osobie, zobowiązany jest do jej naprawienia. Należy tu jednak wyraźnie odróżnić krzywdę, jaka wynikła z zerwania zaręczyn, i z którą nie wiąże się odpowiedzialność cywilnoprawna, od szkody, która została spowodowana w związku z poczynieniem wydatków na uroczystość weselną. Winę $\mathrm{w}$ tej sytuacji ponosi osoba, która doprowadziła do strat majątkowych. Wydaje się, że dochodzenie odszkodowania ograniczone jest do szkody w postaci materialnej i rzeczywistej (damnum emergens). Wykluczone jest dochodzenie tzw. lucrum cessas, czyli korzyści majątkowych, jakich druga strona spodziewała się z wysokim prawdopodobieństwem, a których nie uzyskała w związku z niedojściem do skutku zaślubin. Przeciwko temu rozwiązaniu przemawia niemajątkowy cel małżeństwa w świetle zasad współżycia społecznego ${ }^{49}$.

Oprócz winy narzeczonego oraz zaistnienia szkody, sąd bada również związek przyczynowy pomiędzy działaniem nupturienta a wyrządzoną szkodą. Sąd Najwyższy potwierdza, że ,lekkomyślne spowodowanie kosztów niedoszłego ostatecznie do skutku przyjęcia weselnego stanowi podstawę do żadania stosownego odszkodowania od osoby zrywającej przyrzeczenie małżeństwa" ${ }^{50}$, dodając, że zasada ta odnosi się również do osób trzecich, np. ojca panny młodej, który opłacił koszty zorganizowania wesela. Z podobnym przypadkiem zetknął się Sąd Rejonowy w Gdańsku orzekając, że żadne przepisy nie stoją na przeszkodzie zastosowaniu ogólnych przepisów o odpowiedzialności za wyrządzoną szkodę, i podkreślając, że działanie oskarżanego nupturienta nie musi być nawet lekkomyślne, a w grę wchodzą także działania rozmyślne ${ }^{51}$.

\footnotetext{
${ }^{48}$ A. Kozicka-Puch, Organizacja ślubu i wesela: koszty, zyski, podatki, Polski serwis internetowy z zakresu informacji finansowej, ekonomicznej i gospodarczej www.forsal.pl, [dostęp: 7.7.2017].

${ }^{49}$ Zob. wyrok Sądu Rejonowego w Warszawie z 1.12.2008 r., sygn. akt: VI C 908/06, niepubl.

${ }^{50}$ Wyrok Sądu Najwyższego z 15.7.1953 r., sygn. akt: II C 687/53, Lex nr 196763.

51 Wyrok Sądu Rejonowego Gdańsk - Północ z 30.3.2016 r., sygn. akt: I C 22/15, Portal orzeczeń Sądu Rejonowego Gdańsk - Północ.
} 
Jeśli chodzi o podarunki wręczone osobie zrywającej zaręczyny, niewątpliwie zastosowanie będzie miała instytucja bezpodstawnego wzbogacenia. Istotą tej konstrukcji prawnej jest obowiązek zwrotu przysporzeń, które są nienależne ze względu na brak prawnej zasadności takiego przesunięcia majątkowego ${ }^{52}$. W analizowanej sytuacji mamy do czynienia z tzw. świadczeniem nienależnym. W myśl art. 410 § 2 k.c. świadczenie jest nienależne, jeśli podstawa świadczenia odpadła lub zamierzony cel świadczenia nie został osiągnięty. Zerwanie zaręczyn powoduje odpadnięcie podstawy prawnej świadczeń w postaci prezentów dla przyszłego małżonka. Wobec wniesienia powództwa o zwrot bezpodstawnego wzbogacenia, sąd może nakazać wzbogaconemu zwrot podarunków w naturze, a gdy jest to niemożliwe, spłatę wartości przedmiotu. Świadczenie restytucyjne obejmuje także wszystko to, co wzbogacony uzyskał po zużyciu, utracie lub uszkodzeniu przedmiotu w zamian lub jako naprawienie szkody, co $\mathrm{w}$ doktrynie określa się ,obowiązkiem wydania surogatów"53. Niedoszły małżonek obowiązany jest zwrócić niesłusznie podarowany prezent, jednak bezpłatne rozporządzenie rzeczą na poczet osoby trzeciej, spowoduje przejście na nią tego obowiązku. W doktrynie przyjmuje się, iż powinność ta nie dotyczy już kolejnego obdarowanego ${ }^{54}$.

Zastosowanie znaleźć mogą także regulacje odnoszące się do darowizny. Choć dla bezpieczeństwa darczyńcy art. $890 § 1$ k.c. nakazuje zawarcie umowy darowizny $\mathrm{w}$ formie aktu notarialnego pod rygorem nieważności, to dokonanie jej w innej formie jest ważne, o ile przyrzeczone świadczenie zostało spełnione. Sąd Apelacyjny w Warszawie podkreślił, że ,,w braku aktu notarialnego, $w$ razie jakichkolwiek watpliwości bierze się pod uwage wolę darczyńcy" 55 . W przypadku obdarowania nupturienta prezentem typowo dochodzi do zawarcia umowy darowizny $\mathrm{w}$ formie dorozumianej. Istnieje jednocześnie możliwość odwołania umowy, gdy obdarowany okazuje tzw. rażącą niewdzięcznośćs6 wobec darczyńcy, przy czym doktryna uwzględnia tu także osoby jej najbliższe ${ }^{57}$. Jest ona w każdym przypadku oceniania przez sąd. Nie istnieje oczywiście katalog zachowań, które spełniałyby przesłanki rażącej niewdzięczności. W co najmniej w dobrym tonie jest wyrażanie wdzięczności i przyzwoite zachowanie wobec darczyńcy tuż po dokonaniu darowizny.

\footnotetext{
${ }^{52}$ Z. Radwański, A. Olejniczak, Zobowiązania..., s. 298.

${ }^{53}$ P. Mostowik [w:] A. Olejniczak (red.), System prawa prywatnego. Prawo zobowiązań - część ogólna. Tom 6, wyd. 2, Warszawa 2014, s. 291. Zwrot musi nastąpić niezwłocznie, za opóźnienie należą się odsetki - Ibidem, s. 290 i 295.

54 Ibidem, s. 297.

${ }^{55}$ Wyrok Sądu Apelacyjnego w Warszawie z 1.1.2004 r., sygn. akt: VI CA 826/04, Rejent 2005, nr 3, s. $144-144$.

${ }^{56}$ Zob. bliżej wyrok Sądu Najwyższego z 15.2.2012 r., sygn. akt: I CSK 278/11, Lex nr 1170209.

${ }^{57}$ Np. wyrok Sądu Najwyższego z 2.12.2005 r., sygn. akt: II CK 265/05, Lex nr 707399.
} 
Prezenty ofiarowane niewdzięcznemu nupturientowi potraktować można także jako tzw. darowiznę pod warunkiem, określanym jako ,zastrzeżenie, które uzależnia powstanie lub ustanie skutku prawnego od zdarzenia przyszłego i niepewnego”, które może nigdy nie mieć miejsca ${ }^{58}$. W analizowanej sytuacji nieziszczeniem warunku jest niedojście do skutku małżeństwa, jednak aby można było skorzystać z takiego rozwiązania, konieczne jest zastrzeżenie warunku przy okazji zawierania umowy, co jest niewątpliwie rzadkim zjawiskiem, a w każdym razie 'trudnym dowodowo' w przypadku dokonywania świadczenia w sposób dorozumiany czy też ustny. Zastrzeżenie warunku jest wyłączone w przypadku umowy przenoszącej własność nieruchomości ${ }^{59}$. Nieważne będzie także zawarcie małżeństwa pod warunkiem, co wynika z samej właściwości tego stosunku osobistego ${ }^{60}$.

A co ze złamanym sercem i wyrządzoną krzywdą? Możliwość wystosowania powództwa na podstawie art. 448 w zw. $\mathrm{z}$ art. 24 § 1 k.c. wydaje się wątpliwa. Już w 1965 r. Sąd Najwyższy orzekł: ,,Roszczenie o zawarcie <<umowy matrymonialnej>> przez co powód rozumie zawarcie związku małżeńskiego, nie jest roszczeniem cywilnym i jako takie nie podlega rozpoznaniu przez sady (art. 2 k.p.c.). Inne żądania podniesione w pozwie, jak zwłaszcza żądanie zasądzenia odszkodowania $w$ postaci symbolicznej złotówki za niedotrzymanie przez pozwana obietnicy matżeństwa, jest wprawdzie roszczeniem cywilnym, jednakże oczywiście bezzasadnym, albowiem ustawodawstwo polskie nie zna zadośćuczynienia za niezawarcie przyrzeczonego związu matżeńskiego"'61. Obecnie wskazuje się także na brak możliwości żądania zadośćuczynienia za niedotrzymanie obietnicy małżeństwa ${ }^{62}$. Wydaje się, że o zasadności takiego powództwa może zadecydować jedynie sposób, w jaki nupturient zrywa zaręczyny, publicznie ośmieszając lub znieważając partnera, bądź też jego późniejsze zachowanie w postaci pomówień czy nękania. W takiej sytuacji, oprócz instytucji ochrony dóbr osobistych, sprawiedliwość zapewnia również ustawa karna.

\footnotetext{
${ }^{58}$ Z. Radwański, A. Olejniczak, Prawo cywilne..., s. 289.

${ }^{59}$ Artykuł 157 § 1 k.c.

${ }^{60}$ Z. Radwański, A. Olejniczak, Prawo cywilne ..., s. 292.

${ }^{61}$ Postanowienie Sądu Najwyższego z 28.4.1965 r., sygn. akt: II CR 103/65, Lex nr 5790.

${ }^{62}$ W. Borysiak [w:] J. Wierciński (red.), Kodeks rodzinny i opiekuńczy. Komentarz., Warszawa 2014, s. 19-20.
} 


\section{Odwołanie do uregulowań instytucji zaręczyn w prawie niemieckim i w prawie włoskim}

Warto odnieść się do porządków prawnych innych państw europejskich, w których instytucja zaręczyn została prawnie uregulowana.

Niemiecki kodeks cywilny Bürgerliches Gesetzbuch (BGB) uchwalony w 1896 r. reguluje zaręczyny w księdze czwartej zatytułowanej „Prawo rodzinne”. Odnoszą się do nich normy zawarte w paragrafach 1297-1302. Pierwszy z nich jasno określa, że niemożliwe jest dochodzenie zawarcia małżeństwa przed sądem jakoby roszczenia wynikającego z zaręczyn. Ponadto zabronione jest zastrzeganie kary umownej na wypadek ich zerwania. Takie wskazanie jest o tyle ważne, że w przeszłości w prawie niemieckim istniała możliwość przymuszenia nupturienta do zawarcia małżeństwa, poprzez kapłana, który osobiście wypowiadał sakramentalne „tak” za opierającego się narzeczonego ${ }^{63}$. Uwzględniona została również możliwość dochodzenia odszkodowania, a także obowiązek zwrotu prezentów. Paragraf 1298 stanowi, że osoba, która bez ważnego powodu zerwała zaręczyny ponosi odpowiedzialność odszkodowawczą wobec narzeczonego, jego rodziców, ale też osób trzecich, które działały w miejsce rodziców. Szkoda bowiem istnieje w postaci wydatków poczynionych odnośnie oczekiwań związanych z zawarciem związku małżeńskiego. Uwzględniona jednak została tzw. zasada zdrowego rozsądku przy zawieraniu zobowiązań w związku z organizacją zaślubin, które muszą zostać spłacone. Odpowiedzialności nie ponosi nupturient, który zerwał zaręczyny z istotnego powodu. W paragrafie 1299 do zapłaty odszkodowania została również zobowiązana osoba, która wzbudziła ważny powód, na skutek którego zaręczyny zostały zerwane. W doktrynie prawa niemieckiego przeważa pogląd, zgodnie z którym zaręczyny przybierają postać umowy, w stosunku do której stosowane są przepisy zawarte w części ogólnej kodeksu cywilnego, a wyłączone te z zakresu zobowiązań, jako że w tym wypadku niemożliwym jest dochodzenie wykonania zobowiązania, tj. zawarcia związku małżeńskiego ${ }^{64}$.

Włoski Codice Civile z 16.3.1942 r. w księdze pierwszej zatytułowanej „O osobach i o rodzinie" w art. 79-81 ustanawia prawne regulacje della promessa di matrimonio. Rozwiązanie włoskie jest nieco bardziej skomplikowane, bowiem dla odpowiedzialności odszkodowawczej niedoszłego małżonka znaczenie ma nie tylko wyrządzenie szkody, ale przede wszystkim forma zawarcia zaręczyn. Aby można było żądać odszkodowania za wydatki poczynione W związku z ceremonią zaślubin, fakt zawarcia zaręczyn musi zostać stwierdzony dokumentem

\footnotetext{
${ }^{63}$ A. Szymocha, Zaręczyny w prawie niemieckim i polskim, „Kwartalnik Prawa Prywatnego”, 2013, z. 2, s. 405.

${ }^{64}$ Ibidem, s. 407-408.
} 
urzędowym lub poświadczony podpisem osoby pełnoletniej ${ }^{65}$ albo publicznie ogłoszony. Artykuł 81 Codice Civile stanowi bowiem, że dopiero po spełnieniu powyższych warunków można żądać odszkodowania od zrywającego zaręczyny bez ważnego powodu lub też od nupturienta, z winy którego druga strona się rozmyśliła. Ponadto art. 80 kodeksu przewiduje możliwość dochodzenia zwrotu darowizn dokonanych w związku z obietnicą małżeństwa. Ustawodawstwo włoskie opowiadając się za koncepcją nadającą zaręczynom charakter umowy, odmawia jednocześnie możliwości wywodzenia z faktu ich zawarcia roszczenia o zawarcie małżeństwa ${ }^{66}$.

\section{Uwagi końcowe}

Zaręczyny są głęboko zakorzenionym w historii obyczajem, który pomimo niezwykle szybkiego rozwoju społecznego i całego szeregu zmian zasad komunikacji społecznej, jakie zachodzą na tle postępu technologicznego, dla wielu osób pozostają instytucją bardzo wartościową. Prawdą jest, że częściowo straciły na powadze, bowiem umniejszona została często wyjątkowo oficjalna forma, ale też mniej rygorystycznie postrzega się skutki, jakie wynikają z takiej obietnicy. Mimo to, jak należy sądzić, jeszcze długo będą wydarzeniem cennym i symbolicznym o określonym znaczeniu. Deklaracja zaręczyn wywołuje skutki nie tylko w sferze osobistej, ale i prawnej.

Prawna regulacja instytucji zaręczyn została zniesiona, jak argumentowano, wobec coraz mniejszego ich znaczenia, a także ich nieprzystawania do prawa rodzinnego. Podkreślano, że hipotetyczne problemy z nimi związane można rozwiązać stosując normy prawa obligacyjnego ${ }^{67}$.

Wzajemne roszczenia byłych narzeczonych stanowią przedmiot sporów i rozważań przedstawicieli doktryny, a także orzecznictwa sądowego. Czy nie byłoby dobrym

\footnotetext{
${ }^{65}$ Związek małżeński może również zawrzeć osoba małoletnia, jeśli ukończyła szesnasty rok życia oraz zostały spełnione przesłanki określone w art. 84 Codice civile.

${ }^{66}$ W. Abraham, op.cit., s. 87.

${ }^{67}$ A. Zielonacki, Zawarcie małżeństwa, Wrocław 1982, s. 14, [za:] J. Gajda [w:] T. Smyczyński (red.), System prawa prywatnego. Prawo rodzinne i opiekuńcze. Tom 11, Warszawa 2009, s. 73.
} 
rozwiązaniem normatywne uregulowanie instytucji zaręczyn? Ułatwiłoby dochodzenie należnych roszczeń a jednocześnie, zwiększyłoby rangę i trwałość instytucji małżeństwa ${ }^{68}$.

\begin{abstract}
Summary
Attempt of capture the legal nature of the engagement institution and the consequences

of breaking the promise in the light of Polish law with the indication of the regulation contained in German and Italian law.

When the legal regulation of engagement was abolished from the Polish legislation, there was widespread belief in the legal environment, that there was no need for such legal codification. The meaning of the promise of marriage was rather reduced into a historical custom, which is rooted in the past, denying its legal significance. Today, doctrine adopts various concepts that could determine the legal nature of the engagement. Except of pointing out the historical features of the engagement institution, the article includes theoretical reflections on the nature of the legal promise of marriage. From the practical point of view of this custom, it is also very important to indicate the legal solutions that might apply in the situation of possible liability of the fiancé who has broken the promise, in connection with the expenses incurred for the organization of the wedding. The paper is complemented by a reference to the juridical regulations of engagement in German and Italian law.
\end{abstract}

\title{
Monika Jenda
}

Studentka V roku prawa na Wydziale Prawa i Administracji UKSW w Warszawie, uczestniczka seminarium w Katedrze Prawa Cywilnego, były wolontariusz Uniwersyteckiej Studenckiej Poradni Prawnej WPiA UKSW, wolontariusz Fundacji Academia Iuris im. Macieja Bednarkiewicza w Warszawie. Główne zainteresowania: prawo cywilne, w szczególności odpowiedzialność odszkodowawcza, prawo medyczne, prawo własności intelektualnej oraz fotografia.

\footnotetext{
${ }^{68}$ R. Sztychmiler, Postulaty aksjologiczne polskiego prawa rodzinnego, [w:] B. Czech (red.), Czy potrzebna jest w Polsce zmiana prawa rodzinnego i opiekuńczego, Katowice 1997, s. 71, [za:] G. Jędrejek, Regulacja instytucji malżeństwa w prawie kanonicznym i świeckim, ,Ruch prawniczy, ekonomiczny i socjologiczny”, 2008, z. 2, s. 54 .
} 